\title{
Overview of Approaches to Incorporate Dynamics into the Measurement of Complex Phenomena with the Use of Composite Indices
}

\author{
Anna Łatuszyńska ${ }^{1}$
}

\begin{abstract}
Composite indices have substantially gained in popularity in recent years. Despite their alleged disadvantages, they appear to be very useful in measuring the level of certain phenomena that are too complex to express with a single indicator. Most rankings based on composite indicators are created at regular intervals, such as every month, every quarter or every year. A common approach is to base rankings solely on the most current values of single indicators, making no reference to previous results. The absence of dynamics from such measurements deprives studies of information on change in these phenomena and may limit the stability of classifications.

This article presents the possibility of creating reliable, dynamic rankings of measured items and measuring the complex phenomena with the use of composite indices. Potential solutions are presented on the basis of a review of the international literature. Some advantages and disadvantages of the presented solutions are described and an example of a new approach is shown.
\end{abstract}

KEY WORDS: $\quad$ composite index, complex phenomena, dynamics

JEL Classification: $\quad \mathrm{C} 1, \mathrm{O} 1$

${ }^{1}$ University of Szczecin, Poland

\section{Introduction}

Composite indices, understood as aggregated ordinal or cardinal measures of country performance and created through the manipulation of individual indicators (Saltelli, 2007), have substantially gained in popularity in recent years. Despite their alleged disadvantages, which mostly concern the simplified image of phenomena created by them, these indices represent a very convenient tool for comparing and classifying the results achieved by different countries in both social and economic domains. These indices appear to be

$\square$

Corespondence concerning to this article should be addressed to: latuszynska@gmail.com particularly necessary for measuring the level of complex phenomena, which cannot be expressed with the use of a single indicator. A significant problem created with composite indices is that an objective measure assigned to a certain phenomenon cannot be found. This phenomenon has led to the creation of numerous rankings in terms of this phenomenon. Each of these rankings uses different indices, and, depending on the variables taken into account in creating the composite index, a certain country can be ranked differently, even if the measured phenomenon is the same. Such situation may lead to justified doubts concerning the quality of such classifications.

Most rankings based on composite indicators are created at regular intervals, such as every month, ev- 


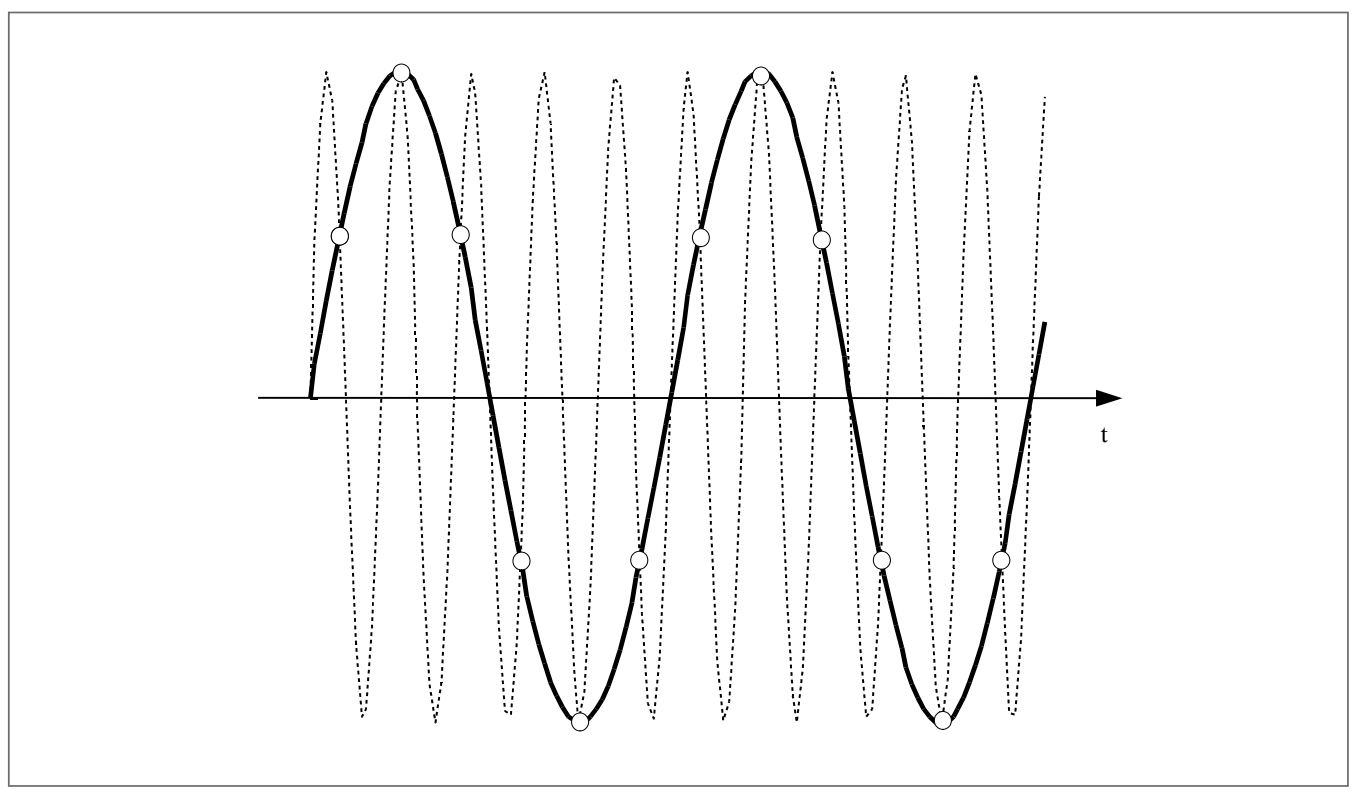

Figure 1. Illustration of Nyquist-Shannon sampling Thorem

ery quarter or every year. A model object (also called a pattern of development), which is the reference point for every comparison, is generally created every time from scratch without considering the results gained in previous research. This approach is not wholly inappropriate, but when the dynamic comparison between measured objects and their individual development over the years or the exact pace of development is demanded, the results of rankings based solely on shortterm model objects may be misleading.

This article presents the possibilities of creating reliable dynamic rankings of measured objects and measuring the complex phenomena with the use of composite indices while avoiding the above-mentioned obstacles. First, the concepts of dynamics and complex phenomena are introduced. Then, the implications for using the composite indices in measuring complex phenomena are explained. As the main part of the paper, the literature analysis concerns the approaches in compliance of dynamics in measuring the complex phenomena. Finally, the conclusions and proposals for possible new solutions are presented.

\section{The Notion of Dynamics}

To clarify the considerations presented in the article, the explanation of a concept that is used often in the text is needed. Dynamics is a widely used concept and is mostly intuitively understood. For this reason, in the literature concerning dynamic phenomena, the definition of this concept is rarely ever explained in detail. The most common explanation is derived from sociology. This term originates in the works of August Comte, the creator of positive philosophy. According his words: "The true general spirit of social dynamics then consists in conceiving of each of these consecutive social states as the necessary result of the preceding, and the indispensable mover of the following, according to the axiom of Leibnitz - the present is big with the future. In this view, the object of science is to discover the laws which govern this continuity, and the aggregate of which determines the course of human development" (Martineau, 1858). In other words, dynamics, as it is currently understood, is a study of how things change over time, a pattern of change or growth of an object or the force or intensity of a phenomenon (Business Dictionary, 2011).

The dynamics of a phenomenon as its changes over time are often measured with the use of statistical tools. Statistics applies dynamics indicators or indices, which are relative numbers showing the ratio or difference between a phenomenon's level during a period under examination and the phenomenon's level during a base period. However, this may be an inadequate 
way to measure the phenomenon's dynamics, as it compares only two periods and shows the change that has happened in the time between them. For example, this method is unable to capture information about dynamics in the longer term. The Nyquist-Shannon (Nyquist, 1928; Shannon, 1949) sampling theorem can be recalled to explain why such a failure is possible. If the sampling interval is too large, information about the signal may be inadequate. Considering the values measured in two points of time could be an example of an inappropriately chosen interval, especially when there is a large span of time between them. This situation is depicted in Fig. 1 in which the dotted line represents the actual run of a phenomenon's values. Circles indicate the points of measurement and the bold solid line is the estimated run of the phenomenon. As it may be observed, such an approach distorts reality. With this explanation in mind, in this article, alternative means of incorporating dynamics into the measurement of complex phenomena and not only the strictly statistical ones, are presented and considered.

\section{The Essence of Complex Phenomena}

In modern societies, researchers often must deal with phenomena that cannot be measured and expressed usefully with a single number. Socio-economic development, the quality of life, the level of satisfaction, the investment attractiveness of regions and the financial state of an enterprise all have many variables and span several domains. All phenomena that can be similarly described are called complex phenomena. In other words, these are all phenomena that must be described with more than one variable.

Socio-economic development is a prime example of the description above. As its name indicates, this concept is by definition connected to the sociological and economic domains. This duality is the strongest premise of the phenomenon's complexity.

Economic development cannot be explained by economic factors alone, and the concept of development includes more than mere changes in economic indicators (Szirmai, 2005, p. 15). Development, conceived of as economic growth, is a quantitative concept. Even if the understanding of development is limited to the economic sphere, it is clear that economic development encompasses more than economic growth alone. Economic development refers to growth accompanied by qualitative changes in the structure of production and employment, generally referred to as structural change (Kuznets, 1966). Development can then be defined as a movement in the direction of developmental goals, which include the reduction of poverty, increased economic welfare, improved health and education, and increased political and social freedom (Szirmai, 2005, p. 9). If any attempt to measure the overall development is to be made, these different domains must be taken into account. This statement is true not only for socioeconomic development but for all complex phenomena as well, provided the selection of relevant variables, adjusted to the measured phenomenon.

\section{Measurement of Complex Phenomena with the Use of Composite Indices}

The current multiplicity of composite indices in use is a consequence of many different methodologies used in the process of constructing such measures. Procedures of creating the composite index can be divided into two groups. There are methods without a model object (pattern of development), which appoint the composite measure as a function of normalised features of an input set. In such methods, the construction of composite indices is dependent on the manner of normalisation. Methods with a model object, also called standard methods, are the second group. These methods imply the existence of a pattern, which serves as the point of reference for the other examined objects. The coordinates of the pattern can be determined on the basis of expert opinions, generally accepted standards or empirical data (Sokołowski \& Zając, 1987). Mosley and Mayer (1998) discuss three approaches to estimating the pattern of development: theoretical, best performance and institutional. Theoretical benchmarks may be based on theoretical economic ideals (for example, zero long-term unemployment). However, for some indicators, these goals are unclear, and because there is likely to be disagreement between economists, the goals are to some extent arbitrary. Best performance may relate to a superior object on a given indicator. Alternatively, it may relate to targets set by institutions, such as international standards.

In general, composite indicators, regardless of their methodology, are far from new measures. Well-known indicators such as the GDP (gross domestic product) and CPI (consumer price index) are used worldwide, 
Table 1. Selected applications of composite indices

\begin{tabular}{|c|c|c|}
\hline Domain & Measured value & Selected indices \\
\hline \multirow{4}{*}{ Environment } & Climate changes & $\begin{array}{l}\text { Climate Analysis Indicators Tool (CAIT), Climate Change Performance } \\
\text { Index (CCPI), Global Climate Risk Index, Index of Social Vulnerability to } \\
\text { Climate Change (SVI) }\end{array}$ \\
\hline & Biodiversity & Living Planet Index (LPI), National Biodiversity Index (NBI) \\
\hline & Exploitation of natural resources & Ecological Footprint, Mineral Extraction Risk Assessment (MERA) \\
\hline & Level of environmental protection & $\begin{array}{l}\text { Environmental Degradation Index (EDI), Environmental Performance } \\
\text { Index (EPI), Environmental Sustainability Index (ESI) }\end{array}$ \\
\hline \multirow{2}{*}{ Government } & Level of democracy & $\begin{array}{l}\text { Countries at the Crossroads, Democracy Score (Nations in Transit Rat- } \\
\text { ings), Governance Indicators }\end{array}$ \\
\hline & Prevalence of e-government & $\begin{array}{l}\text { E-Participation Index, E-Government Readiness Index, E-Government } \\
\text { Index }\end{array}$ \\
\hline \multirow{5}{*}{ Social aspects } & Corruption & $\begin{array}{l}\text { Bribe Payers Index (BPI), Corruption Perception Index (CPI), Global } \\
\text { Integrity Index, }\end{array}$ \\
\hline & Social satisfaction and quality of life & $\begin{array}{l}\text { Basic Capabilities Index (BCI), Global Quality of Living, Happiness } \\
\text { Index, Quality of Life Index }\end{array}$ \\
\hline & Gender equality & $\begin{array}{l}\text { Gender Empowerment Measure (GEM), Gender Equity Index (GEI), } \\
\text { Gender Gaps, Gender Gaps Scores in Education, Gender-related } \\
\text { Development Index (GDI) }\end{array}$ \\
\hline & Malnutrition and poverty & $\begin{array}{l}\text { Food Insecurity, Global Hunger Index (GHI), Human Poverty Index } \\
(\mathrm{HPI})\end{array}$ \\
\hline & Progress and development & $\begin{array}{l}\text { Human Development Index (HDI), Index of Human Progress, Interna- } \\
\text { tional Index of Social Progress (ISP) }\end{array}$ \\
\hline \multirow[b]{2}{*}{ Human rights } & Press freedom & $\begin{array}{l}\text { Media Sustainability Index (MSI), Press Freedom Index, World Press } \\
\text { Freedom Ranking }\end{array}$ \\
\hline & Individual rights & $\begin{array}{l}\text { The Observer Human Rights Index, CIRI Human Rights Dataset, Hu- } \\
\text { man Rights Commitment Index, Political Rights and Civil Liberties } \\
\text { Ratings, }\end{array}$ \\
\hline \multirow{4}{*}{ Economy } & Enterprise & $\begin{array}{l}\text { Ease of Doing Business, Economic Freedom of the Word (EFW) Index, } \\
\text { Global Entrepreneurship Monitor, Global Retail Development Index } \\
\text { (GRDI) }\end{array}$ \\
\hline & E-business & E-Business Readiness Index, E-Readiness Rankings \\
\hline & Investment risk & $\begin{array}{l}\text { Country Risk Rating, Global Risk Service, International Country Risk } \\
\text { Guide (ICRG) Ratings }\end{array}$ \\
\hline & Innovation & $\begin{array}{l}\text { European Innovation Scoreboard (EIS), Summary Innovation Index } \\
\text { (SII), Innovation Capacity Index }\end{array}$ \\
\hline
\end{tabular}

Notes: On the basis of Bandura (2008) 
not only as informational measures but also as policy instruments. However, there are objections to their use because of their inadequacy (Cherchye et al., 2007). Using the GDP as an indicator of development does not reflect citizens' wellbeing, for example. Income indicators do not provide us with a good picture of changes in the life circumstances of the poor, as they are average figures. Furthermore, the level of the national income is not directly related to the standard of living. When a substantial part of a country's national income is invested in the military, the standard of living of this country's inhabitants may lag far behind national income growth (Szirmai, 2005, p. 15). From this perspective, some of the advantages of composite indices can be observed. A more comprehensive picture of development in a country could be provided by the consideration of additional economic and social indicators, such as the following: the number of people below poverty thresholds, data on malnutrition, employment figures, life expectancy at birth, infant mortality, the number of doctors, nurses and hospital beds for every thousand inhabitants, energy consumption, the degree of illiteracy, years of education, data on income distribution, miles of roads and railways, access to clean water, equal opportunities for both men and women, human rights and so forth (Szirmai, 2005, p. 15). A convenient way to combine this number of variables into readable results is composite indices, which can aggregate all of the above-mentioned aspects.

Table 1 presents the most common examples of such composite indices, which are not limited to the context of socio-economic development. As it may be observed, for many of the phenomena, more than one index is used, which can lead to ambiguity in the results of measurement (Jones, 2004).

The multidimensionality of composite indicators is one of these measurements' major advantages. Such indicators are relatively flexible because the methodology of their creation allows, in most cases, the introduction of changes in selection, scaling, weights and aggregation. Composite indices provide the possibility of condensing a large amount of information into readable results, which helps greatly in decisionmaking and policy.

Among the most serious objections against composite indicators worth mentioning are that they often lack a theoretical model explaining the selection of compo- nent indices. They are also criticised for several other reasons. Often, one or more elements essential for certain domains are excluded in favour of less representative variables. A major argument against the use of composite indices is that they usually do not provide any additional information that cannot be provided by a single index (Booysen, 2002) but do require much more data to introduce analysis (Saisana \& Tarantola, 2002).

Existing indicators aggregating single indices are constantly improved to emphasise their advantages and to eliminate the drawbacks of their use. One direction of these improvements is to incorporate a phenomenon's dynamics into measurements, with composite indicators.

\section{Approaches to Compliance of Dynamics in Measuring the Socio-economic Development}

The most common application of composite indices are currently classification (primarily rankings of countries' performance) and forecasting (estimating market trends). Because the world changes very quickly, information on the dynamics of changes appears to be very important. In most publications concerning composite indices and their applications, the dynamics are not directly included and discussed, but this issue is not ignored. This section of the paper presents some of the most popular approaches to incorporate dynamics into measurements of complex phenomena with the use of composite indices. Due to the wide range of both composite indicators' applications and the mathematical methods used to employ them, the scope of this paper is limited to composite indicators used for classification purposes (numerical taxonomy).

Regardless of the methodology and application of the dynamic composite index, it is common for there to be initial steps that must be performed preceding the measurement of a complex phenomenon. These preliminary activities must include the selection of appropriate variables, which are expected to be significantly correlated with the phenomenon. Before the composite index can be calculated, the correlation and analysis of relations between chosen variables must be performed. In the case of strong correlations, some variables can be removed from selection. After this step of refinement, a database with the values of variables measured over a specified time period must 
Table 2. Description of chosen methodologies concerning dynamics in classification

Scope of the research Methodology Publication

The composite indicator is based on a taxonomical measure of de-
velopment proposed by Hellwig (1968). On the basis of collected
data, the origin of a multidimensional coordinate system as the
point of reference (pattern of development) is chosen (variables
are standardised). Then, values of the composite index, calculated
as the distance from the model object, are obtained. On their
basis, variation coefficients for objects and growth rates in certain
periods are calculated. In this case, variation coefficients express
the phenomenon's dynamics.

This idea is again similar to the method proposed by Hellwig (1968). On the basis of the collected data, a pattern of development is established (for each object, pattern should be individual).

Economic research and socio-economic development

Dynamic and spatial comparative analysis of economical structures

Comparative analysis of agricultural production's development

Indicators for social inclusion

Measurement of investment attractiveness of companies listed on stock exchange
Then, the distance between each examined object and its pattern of development is calculated. The dynamics of development are estimated by incrementing between-distances to the pattern obtained in following periods. For each period, the pattern is calculated separately.

In this approach, structural changes in examined objects are measured. The value of the composite indicator is calculated for each adjacent pair of years. Doing so enables following the changes and detecting turning points occurring in objects' trends. For the index of structural changes, a coefficient of volatility of growth indicators for individual elements of the structure is used.

The composite index is calculated as a mean of the variable's values describing the measured object. Knowledge about the indicator's values allows the estimation of the dynamics of the studied phenomenon. Dynamics in this context means the average increment of the phenomenon and the average pace of its growth, which are supplemented with the use of linear and exponential trending.

The value of a composite index is calculated as a weighted mean of single indicators. The dynamics of performance for each studied object are expressed as a percentage change between two periods under research.

This study utilises a dynamic approach to assess the stability of classification. The mean value of differences in the composite indicator's value between two examined periods of time is calculated for all objects. The coefficient obtained reflects the dynamics of change occurring in the meantime. The dynamics in this case are aggregated for all studied objects.
Ditmann \& Pisz, 1975

Pluta, 1977

Zeliaś, 1988

Nowak, 1990

Cherchye et al., 2004 
Table 2. (continued)

\section{Scope of the research Methodology}

Standard of living in
Poland and in the EU

Assessment of the EU's internal market

Regional development
The composite index is calculated on the basis of the distance between the measured object and the pattern of development. Three different approaches concerning the choice of reference point were considered: a model with a constant pattern for the base year of research; a model with a volatile pattern, calculated as the mean value of variables in corresponding periods of time; and a model with pattern including optimal (best) values of analysed variables in certain periods. The constant variance of the pattern enables the comparison of obtained values of an index to the base year's value. The volatile approach presents the best possible performance that could be achieved in a certain year.

In this approach, the dynamics of each sub-indicator included in the composite index are calculated as the ratio between the value of an indicator in a certain period to its value in the base interval of time. After the dynamics of all sub-indicators are obtained, a weighted aggregation of the results is made. On this basis, the performance of examined countries is evaluated.

The composite indicator is based on vector calculus. The chosen standard object (which can be described as pattern of development) is the one that has maximal values among stimulants and minimal among destimulants. This pattern can be constant and does not depend on the number of periods that are taken into account in the research. This approach allows other examined objects to be better than the standard one. Using the same pattern for the entire period under study, it is possible to compare objects' performances in subsequent intervals of time.

\section{Publication}

Zeliaś et al., 2004

Cherchye et al., 2007 be created. The values to be included in this database are then used to create a composite index. These values must be normalised, and suitable weights should be assigned to them. The following steps, which concern the exact rules and formulas for calculations, differ depending on the researchers' methodology.

Table 2 lists some approaches that incorporate dynamics into the creation of composite indicators. All of the presented studies concern the taxonomy of examined objects on the basis of the composite indicator's value. In most of the presented approaches, the dynamics of the phenomenon are measured with the use of simple statistical tools. Indicators or indices are calculated that show the ratio or difference between the phenomenon's level in the examined period and the phenomenon's level in the base period. As was mentioned previously, this approach to measuring the phenomenon's dynamics may be insufficient. The information obtained in this case applies only to change between two exact points in time and does not depict the trend of a phenomenon in the interim.

The group of approaches based on the pattern of development suggested by Hellwig (1968) could eliminate the problem mentioned above but requires a large number of calculations. In this approach, a possible cause of confusion is that in research concerning more intervals, the model object calculated in the base interval cannot be used directly for subsequent periods of time. The rule of calculating the distance between measured objects and their point of reference (the base 

społeczno-ekonomicznych [Dynamical method of spatial differentiation of socio-economic phenomena]. Wiadomości Statystyczne, XX(11), 27-28.

Hellwig, Z. (1968). Zastosowanie metody taksonomicznej do typologicznego podziału krajów ze względu na poziom ich rozwoju oraz zasoby i strukturę wykwalifikowanych kadr [Application of taxonomical method to the topological classification of countries on the basis of their development's level and qualified workers structure]. Przeglad Statystyczny, 4, 307-327.

Jones, M. (2004). Dynamic benchmarking of the Welsh labour market. Regional Studies, 38(5), 495-506.

Kuznets, S. (1966). Modern Economic Growth. New Haven, CT: Yale University Press.

Martineau, H. (1858). Positive philosophy of August Comte freely translated and condensed by Harriet Martineau. New York, NY: Calvin Blanshard.

Mosley, H. \& Mayer, A. (1998). Benchmarking National Labour Market Performance: A Radar Chart Approach. Report for the European Commission, Directorate-General V, Employment, Industrial Relations and Social Affairs (DGV/A2).

Nermend, K. (2009). Vector Calculus in Regional Development Analysis: Comparative Regional Analysis Using the Example of Poland. Berlin Heidelberg: Physica-Verlag.

Nowak, E. (1990). Metody taksonomiczne w klasyfikacji obiektów społeczno-gospodarczych [Taxonomical methods in classifying socio-economic objects]. Warszawa: PWE.

Nyquist, H. (1928). Certain topics in telegraph transmission theory. Transactions of the American Institute of Electrical Engineers, 47(2), 617-644.

Pluta, W. (1977). Wielowymiarowa analiza porównawcza $w$ badaniach ekonomicznych [Multidimensional comparative analysis in economic research]. Warszawa: PWE.

Saisana, M. \& Tarantola, S. (2002). State-of-the-art Report on Current Methodologies and Practices for Composite Indicator Development. Institute for the Protection and Security of the Citizen Technological and Economic Risk Management. Retrieved from http://composite-indicators.jrc.ec.europa. eu/Document/state-of-the-art_EUR20408.pdf

Saltelli, A. (2007). Composite indicators between analysis and advocacy. Social Indicators Research, 81, 65-77.
Shannon, C. E. (1949). Communication in the presence of noise. Proceedings of the Institute of Radio Engineers, 37, 10-21.

Sokołowski, A., \& Zając, K. (1987). Rozwój demograficzny a rozwój gospodarczy [Demographic development vs. economic development]. Warszawa: PWE.

Szirmai, A. (2005). Dynamics of socio-economic development: an introduction. Cambridge: Cambridge University Press.

Tarczyński, W. (2004). Dynamiczne ujęcie taksonomicznej miary atrakcyjności inwestycji na przykładzie wybranych spółek notowanych na giełdzie papierów wartościowych w Warszawie [Dynamic aspects of taxonomic measure of investment attractiveness: the example of selected companies listed on Warsaw Stock Exchange]. Zeszyty Naukowe Uniwersytetu Szczecińskiego, 394(15), 299 - 322.

Zeliaś, A. (Ed.). (1988). Metody statystyki międzynarodowej [Methods of international statistics]. Warszawa: PWE.

Zeliaś, A. (Ed.). (2004). Poziom życia w Polsce i krajach Unii Europejskiej [The level of life in Poland and in $E U]$. Warszawa: PWE. 
